\title{
Concomitant Deficits in Working Memory and Fear Extinction Are Functionally Dissociated from Reduced Anxiety in Metabotropic Glutamate Receptor 7-Deficient Mice
}

\author{
Zsuzsanna Callaerts-Vegh, ${ }^{1}$ Tom Beckers, ${ }^{2}$ Simon M. Ball, ${ }^{3}$ Frank Baeyens, ${ }^{2}$ Patrick F. Callaerts, ${ }^{4}$ John F. Cryan, ${ }^{5}$ \\ Elek Molnar, ${ }^{3}$ and Rudi D'Hooge ${ }^{1}$ \\ ${ }^{1}$ Laboratory of Biological Psychology and ${ }^{2}$ Center for Learning Psychology and Experimental Psychopathology, Department of Psychology, University of \\ Leuven, B-3000 Leuven, Belgium, ${ }^{3}$ Medical Research Council Centre for Synaptic Plasticity, Department of Anatomy, University of Bristol, Bristol BS8 1TD, \\ United Kingdom, ${ }^{4}$ Laboratory of Developmental Genetics, Flemish Interuniversity Institute of Biotechnology-University of Leuven, Center for Human \\ Genetics, B-3000 Leuven, Belgium, and 5 Nervous System Research, Novartis Institutes for BioMedical Sciences, Novartis Pharma AG, CH-4002 Basel, \\ Switzerland
}

Metabotropic glutamate receptor 7 (mGluR7), a receptor with a distinct brain distribution and a putative role in anxiety, emotional responding, and spatial working memory, could be an interesting therapeutic target for fear and anxiety disorders. mGluR7-deficient $\left(m G l u R 7^{-1-}\right)$ mice showed essentially normal performance in tests for neuromotor and exploratory activity and passive avoidance learning but prominent anxiolytic behavior in two anxiety tests. They showed a delayed learning curve during the acquisition of the hidden-platform water maze, and three interspersed probe trials indicated that $m G l u R 7^{-/-}$mice were slower to acquire spatial information. Working memory in the water maze task and the radial arm maze was impaired in $m G l u R 7^{-/-}$mice compared with $m G l u R 7^{+/+}$. $m G l u R 7^{-1-}$ mice also displayed a higher resistance to extinction of fear-elicited response suppression in a conditioned emotional response protocol. In a non-fear-based water maze protocol, $m G l u R 7^{-1-}$ mice displayed similar delayed extinction. These observed behavioral changes are probably not attributable to changes in AMPA or NMDA receptor function because expression levels of AMPA and NMDA receptors were unaltered. Extinction of conditioned fear is an active and context-dependent form of inhibitory learning and an experimental model for therapeutic fear reduction. It appears to depend on glutamatergic and higher-level brain functions similar to those involved in spatial working memory but functionally dissociated from those that mediate constitutional responses in anxiety tests.

Key words: metabotropic glutamate receptors; fear and anxiety; fear extinction; conditioned emotional response; learning and memory; operant

\section{Introduction}

Glutamate is the dominant excitatory neurotransmitter in the mammalian CNS, eliciting its actions through ionotropic and metabotropic receptors. Eight metabotropic glutamate receptor (mGluR) subtypes have been identified and divided into three groups based on sequence homology, pharmacology, and coupling to different signaling pathways (Kew and Kemp, 2005). Metabotropic glutamate receptor 7 (mGluR7) is a member of the

Received Nov. 10, 2005; accepted April 25, 2006.

The project was financially supported by Fonds voor Wetenschappelijk Onderzoek (FW0)-Vlaanderen Grant G.0271.06 and the Katholieke Universiteit Leuven 2004 Impulse Programme. Z.C.-V. is a Postdoctoral Fellow of the Katholieke Universiteit Leuven. T.B. is a Postdoctoral Fellow of FWO-Vlaanderen. We thank Ellen Gillard and Leen Van Aerschot for excellent technical assistance and Novartis Pharma AG for providing mGluR7 knock-out mice.

Correspondence should be addressed to Dr. Rudi D'Hooge, Laboratory of Biological Psychology, Tiensestraat 102, 3000 Leuven, Belgium. E-mail: rudi.dhooge@psy.kuleuven.be.

John F. Cryan's present address: School of Pharmacy, Department of Pharmacology and Therapeutics, University College Cork, Cork, Ireland.

D0I:10.1523/JNEUROSCI.1497-06.2006

Copyright $\odot 2006$ Society for Neuroscience $\quad$ 0270-6474/06/266573-10\$15.00/0 group III family of mGluRs that bind to $\mathrm{G}_{\mathrm{i}}$ and inhibit adenylate cyclase. It is the most highly conserved mGluR subtype in mammalian species (Makoff et al., 1996), abundantly expressed in CNS regions implicated in fear and anxiety states such as amygdala and hippocampus. Presynaptic mGluR7s modulate the release of neurotransmitters such as GABA, L-glutamate, and possibly monoamines (Schoepp, 2001). Specific mGluR7 ligands were not available until recently, but studies in mGluR7-deficient mice confirm that mGluR7 plays an important role in controlling neuronal excitability (Sansig et al., 2001).

Fear and anxiety disorders are a major health concern (National Institute of Mental Health, 2001), but current therapeutic strategies based on anxiolytic drug treatment and fear extinction procedures are ineffective in a proportion of patients, and novel approaches to target the neuronal substrates of fear and anxiety are definitely required (Myers and Davis, 2002; Swanson et al., 2005; Craske et al., 2006). It is not clear, however, whether anxiety tests that are used in preclinical studies on anxiolytic drugs, and 
extinction procedures based on the classical model of fear conditioning (Pavlov, 1927), actually have a common substrate. Although the neurobehavioral basis of fear acquisition is well understood (Maren, 2001), less is known about mechanisms underlying extinction (Myers and Davis, 2002). Because extinction is now considered to be an active and context-dependent form of learning inhibiting the expression of conditioned fear responses (Bouton, 2002, 2004; Rescorla, 2004), it may depend on higher-level cognitive processes similar to those involved in working memory (Carter et al., 2003).

Along with other mGluRs, mGluR7 could be a promising drug target for affective disorders such as anxiety and depression (Linden et al., 2002; Cryan et al., 2003; Swanson et al., 2005). Behavioral studies in mGluR7-deficient mice indicate an involvement of mGluR7 in specific aspects of anxiety and emotional responding (Cryan et al., 2003; Mitsukawa et al., 2005). Additionally, Holscher et al. (2004) described deficits in spatial working memory in these mice, suggesting that the model could be suitable to investigate the association between higher-level cognitive processes, anxiety, and fear conditioning.

In this study, we examined the role of mGluR7 in anxiety, extinction of conditioned responses, and spatial working memory. Specific tasks were used to examine the possible involvement of this receptor in these conceptually diverse neurobehavioral phenomena. Different anxiety tests were included, and, in relation to the hypothetical association between these functions, we investigated the possible concomitance of defects in spatial working memory (as a rodent model for higher-level cognitive processes) and acquisition/extinction in the Morris water maze task as well as in a conditioned emotional response (CER) procedure, a controlled and well characterized method to investigate fear conditioning (Davis, 1990).

\section{Materials and Methods \\ Animals \\ $m G l u R 7^{-1-}$ mice were generated and extensively backcrossed (more than F14 generations) to C57BL/6 background as described previously (Sansig et al., 2001). Age-matched $m G l u R 7^{+/+}$littermates were used as controls, and genotypes were confirmed by PCR. Mixed genotype groups were kept in standard animal cages under conventional laboratory con- ditions ( $12 \mathrm{~h}$ light/dark cycle, $22^{\circ} \mathrm{C}$ ), with ad libitum access to food and water (unless stated otherwise). Gender-mixed groups of animals aged $8-10$ weeks were used for behavioral experiments, which were all con- ducted during the light phase of their activity cycle. For neuromotor and exploratory tasks (i.e., rotarod, grip strength, activity, passive avoidance, elevated plus maze, open field, and social exploration) and CER, one cohort of mice was tested, whereas for the remaining tasks, other naive mice were used. All protocols have been reviewed and approved by the animal experiments committee of the Katholieke Universiteit Leuven and were performed in accordance with the European Community Council Directive (86/609/EEC).}

\section{Neuromotor and visual performance}

Because alterations in neuromotor and visual performance can markedly confound performance in behavioral tests, we first assessed cage activity, grip strength, and motor coordination and visual abilities in $m G l u R 7^{-1-}$ mice.

Cage activity. Cage activity was recorded using a laboratory-built activity logger connected to three infrared photo beams. Mice were placed individually in $\sim 20 \times 26 \mathrm{~cm}^{2}$ transparent cages located between the photo beams. Over a period of $24 \mathrm{~h}$, activity was measured and expressed as beam crossings for each $30 \mathrm{~min}$ interval.

Grip strength. Grip strength was measured using a device consisting of a 10-cm-long T-shaped bar connected to a digital dynamometer (Ugo Basile, Comerio, Italy). Mice were placed before the bar, which they usually grabbed spontaneously, and gently pulled backwards until they released the bar (maximal readouts were recorded). Ten consecutive measurements for each animal were averaged. No fatigue was observed over this testing period.

Motor coordination. Motor coordination and equilibrium were tested on an accelerating rotarod designed for mice (Med Associates, St. Albans, VT). Mice were first trained at constant speed (4 rpm, $2 \mathrm{~min}$ ) before starting with four test trials (intertrial interval, $10 \mathrm{~min}$ ). During these test trials, the animals had to balance on a rotating rod $(3.2 \mathrm{~cm}$ diameter, 5.7 $\mathrm{cm}$ width, $16.5 \mathrm{~cm}$ drop height) that accelerated from 4 to $40 \mathrm{rpm}$ in 5 $\mathrm{min}$, and time until they dropped from the rod was recorded (up to the 5 min cutoff).

Visual evoked potentials were recorded on a Myos 4 plus digital EMG/EP recorder (Schwarzer, Munich, Germany) to assess whether $m G l u R 7^{-1-}$ have normal vision. A platinum electrode was placed subcutaneously between the eyes, and a reference electrode and a ground lead were placed subcutaneously at the base of the skull and tail, respectively. Two hundred light flash stimuli were presented, and the responses were averaged.

\section{Exploratory activity and defensive burying}

Exploratory behavior in a novel environment was examined in the openfield, social exploration, and elevated plus maze tests. In addition, the marble-burying task was performed. These conflict tasks can be used to measure anxiety-related behavior in mice.

Open-field exploration. Open-field exploration was examined using a $50 \times 50 \mathrm{~cm}^{2}$ square arena, which was illuminated by indirect light. Animals were dark adapted for $30 \mathrm{~min}$ and placed in the arena for $10 \mathrm{~min}$ each. Movements of the mice in the arena were recorded using EthoVision video tracking equipment and software (Noldus, Wageningen, The Netherlands). Total path length and corner crossings were included as measures of locomotor activity. These measures are highly correlated and mainly indicate thigmotactic walking near the walls of the arena. Entries into the center of the field were recorded as a measure of conflict resolution or anxiolysis.

Social interaction. Social interaction is another measure of anxiety (File and Seth, 2003). The amount of time spent in social exploration was measured in the open-field arena by placing two female mice in a centrally located cage enabling visual, olfactory, and limited physical contact with the tested male mouse. Mice started from a specific corner of the arena, and recording of the explorative pattern began after 1 min of adaptation. Total path lengths as well as number of entries and path length in the center circle during $10 \mathrm{~min}$ trial duration were recorded as measures of social exploration.

Elevated plus maze. The elevated plus maze was used to assess anxietyrelated exploration. The arena consisted of a plus-shaped maze with two arms $(21 \times 5 \mathrm{~cm})$ closed by high side walls and two arms without walls. The maze was located $30 \mathrm{~cm}$ above the table surface. Mice were placed at the center of the maze and were allowed to explore freely for $10 \mathrm{~min}$. Exploratory activity was recorded by five infrared beams (four for arm entries and one for open-arm dwell) connected to a computerized activity logger.

Defensive burying test. The marble-burying test is another task to assess anxiety-related behavior such as obsessive-compulsive disorders that has shown reliable correlation with antidepressant activity (Borsini et al., 2002; Cryan and Holmes, 2005). Whereas in many other tasks anxiolytic behavior is characterized by increased responding (e.g., increased openarm entries in plus maze), the marble-burying test will actually show a decrease in active responding (i.e., number of marbles buried) and is therefore a good complementary test in an anxiety screening test battery (Cryan and Holmes, 2005). Mice were placed individually in transparent plastic cages $(15 \times 26 \times 42 \mathrm{~cm})$ containing $5 \mathrm{~cm}$ of sawdust and 24 identical glass marbles $(\sim 1.5 \mathrm{~cm}$ diameter) evenly spaced $2 \mathrm{~cm}$ from the cage wall (Njung'e and Handley, 1991; Millan et al., 2000). The cages were placed on a platform $80 \mathrm{~cm}$ above the floor and under bright illumination. After $30 \mathrm{~min}$, the mice were returned to their home cage, and the number of marbles buried two-thirds by saw dust was counted.

\section{Learning and memory tasks}

Passive avoidance learning. Passive avoidance learning was assessed in a two-compartment box with a shock grid (D'Hooge et al., 2005). This task 
allows measurement of avoidance behavior and learning abilities in mice. The box consisted of an illuminated compartment and a dark compartment, separated by a guillotine door. After 30 min adaptation to a dark environment, the subject was placed in the light part, and latency to enter the dark compartment was measured. If the subject failed to enter the dark compartment within 5 min trial duration, it was gently probed to enter the dark part. On entry into the dark compartment, the door was closed and a $2 \mathrm{~s}$ footshock $(0.2 \mathrm{~mA})$ was applied. The mouse was then removed from the box and placed in its home cage. Twenty-four hours later, the dark-adapted mouse was again placed in the light box and latency to enter the dark compartment was measured.

Morris water maze. Spatial memory abilities were examined in the standard hidden-platform acquisition and retention (i.e., long-term memory) and working memory versions of the Morris maze (Stewart and Morris, 1993). A circular pool (diameter, $150 \mathrm{~cm}$ ) was filled with water, opacified with nontoxic white paint, and kept at $26^{\circ} \mathrm{C}$ as described previously (D'Hooge et al., 2005). A round platform (diameter, $15 \mathrm{~cm}$ ) was hidden $1 \mathrm{~cm}$ beneath the surface of the water at a fixed position. Swimming paths of the animals were recorded using EthoVision video tracking equipment and software (Noldus).

Acquisition of reference memory. Each daily trial block consisted of four swimming trials (10-15 min intertrial interval) starting randomly from each of four starting positions. Mice that failed to find the platform within 2 min were gently guided to the platform, where they remained for $15 \mathrm{~s}$ before being returned to their cages. Escape latency to find the hidden platform, path length, swim velocity, and the time spent near the wall (thigmotaxis) were recorded. Interspersed probe trials were conducted $3 \mathrm{~h}$ after the last acquisition trial in a working week (usually on Friday afternoons or after 13 trial blocks). During these probe trials, the platform was removed from the pool, and the search pattern of the mice was recorded for $100 \mathrm{~s}$. Three such probe trials were conducted.

After establishing a stable acquisition curve and a clear preference for the target quadrant during probe trials, the animals were subjected to either a working memory task or an extinction task.

Working memory task in Morris water maze. On a subset of animals ( $n=12$ and 17 for $m G l u R 7^{+/+}$and $m G l u R 7^{-/-}$, respectively) a test of working memory was administered. In this test, the location of the hidden platform was changed between each trial block. Each daily trial block consisted of five swimming trials of 2 min: the first trial was regarded as a cue trial, followed by four swimming trials (30 min intertrial interval), which were used to calculate average escape latency. For the first six trial blocks, the position of the platform during cue and during the following four swimming trials was the same (spatial cue experiment). In an additional experiment of six trial blocks, we changed the position of the platform for the four swimming trials to the opposite quadrant of the one in the cue trial (uncued experiment).

Extinction of reference memory in Morris water maze. A different subset of animals ( $n=14$ and 14 for $m G l u R 7^{+/+}$and $m G l u R 7^{-/-}$, respectively) performed an extinction task with removed platform. Each trial block consisted of four swimming trials of $100 \mathrm{~s}$ (10 min intertrial interval) starting randomly from each of four starting positions. Two, three, and three trial blocks were performed on 3 consecutive days. Time in target quadrant, path length, swim velocity, time spent floating [defined as swim velocity $<5 \mathrm{~cm} / \mathrm{s}$ (Lattal et al., 2003)], and the time spent near the wall (thigmotaxis) were recorded.

Radial arm maze. Working memory was assessed using a radial arm maze. In contrast to the water maze, the radial arm maze has been more commonly used to assess working memory abilities (based on proximal cues in a less aversive environment). The dark gray polyvinyl chloride arena consisted of a central round platform (diameter, $40 \mathrm{~cm}$ ) from which eight enclosed arms $(40 \times 8 \mathrm{~cm}$ with a 5 -cm-high wall $)$ radiated. Manually operated guillotine doors allowed the closing of individual arms. At the end of each arm, a small food cup inserted in a hole contained the food bait. The maze was situated $80 \mathrm{~cm}$ above the floor and comprised extramaze cues as well as different black-and-white signs posted at the arm entrances. A large cylinder made of black paper was placed on the platform at the start of the trial, and the mouse was placed inside the cylinder. After $10 \mathrm{~s}$, the trial was started by lifting the paper cylinder to allow access to the arms. After $5 \mathrm{~d}$ of handling and habituation to the maze $(5 \mathrm{~min} / \mathrm{d})$, subjects were trained in the standard radial maze tasks (eight choices) in one daily session. Each food cup contained a food bait (chocolate-covered Rice Krispies; Kellogg's, Battle Creek, MI), and the mouse was to obtain all food pellets within $5 \mathrm{~min}$. The session ended when the subject either retrieved all eight food pellets or $5 \mathrm{~min}$ had passed. No visit or a repeat visit to an arm was counted as an error. After obtaining a stable rate of two or less errors per run, mice were tested in a delayed non-matching-to-sample test for working memory assessment. Four randomly assigned arms were baited; the subject was placed on the platform and time to collect all four baits was measured. After retrieval of all four baits, the subject was replaced in its home cage for $1 \mathrm{~h}$. With all arms accessible but only the previously closed arms now baited, the subject was again placed on the platform. Time to retrieve all four food pellets was recorded, as well as errors of visiting unbaited arms and revisit of baited arms.

\section{Fear conditioning: CER procedure}

Instrumental learning and acquisition and extinction of CER were tested in an automated operant chamber (Coulbourn Instruments, Allentown, PA) essentially as described previously (Van Dam et al., 2000). Before the start of training, the animals were placed on a food restriction schedule to keep their body weights at $80-90 \%$ of their free-feeding weights. They were then trained by gradual shaping to nose poke for food pellets (Noyes precision pellets; Research Diets, New Brunswick, NJ). During the 30 min training sessions, mice were able to obtain food pellets by using the nose-poke device inside the cages. Mice received food rewards during all trials throughout the experiment, but the reinforcement schedule was gradually changed to arrive at a stable response rate. Training started with five continuous reinforcement (CRF) sessions (i.e., every nose poke was rewarded), followed by six fixed ratio (FR) sessions (three FR-5 sessions and three FR-10 sessions, in which every fifth and every 10th nose poke was rewarded, respectively), ending with six variable interval (VI) sessions, VI-30s (i.e., an average interval of $30 \mathrm{~s}$ was interposed between reinforced responses). Rate of nose poking in each session was recorded. Next, a cued fear conditioning procedure was superimposed on the instrumental responding (CER procedure) (Davis, 1990). In eight CER acquisition sessions, $0.2 \mathrm{~mA}$ shocks were presented with a random 3 min interval. Shocks were signaled by $20 \mathrm{~s}$ auditory SonAlert signals, which coterminated with the $0.2 \mathrm{~s}$ shock, while nose poking continued to be reinforced on a VI-30 s schedule. In eight post-CER extinction sessions, $20 \mathrm{~s}$ SonAlert signals were again presented with random $3 \mathrm{~min}$ intervals but were no longer followed by shock, while nose poking continued to be reinforced as before. For each CER and post-CER session, rate of nose poking during the auditory cues was compared with rate of nose poking during the interstimulus intervals by means of a suppression ratio (SR), given as follows: $S R=R R_{C U E} /\left(R_{C U E}+R R_{I S I}\right)$, with $R R_{C U E}$ and $\mathrm{RR}_{\mathrm{ISI}}$ representing mean response rates in the presence and absence of the auditory cues, respectively. As such, an SR of 0.5 indicates complete lack of suppression (equal response rates in the presence and absence of the cues), whereas an SR of 0 indicates complete suppression (complete lack of responding in the presence of the cues).

\section{Histoblot analysis of AMPA and NMDA receptor protein expression}

Brains from three wild-type $\left(m G l u R 7^{+/+}\right)$and three mGluR7-deficient transgenic $\left(m G l u R 7^{-1-}\right)$ adult mice were used to determine changes in the distribution of AMPA- and NMDA-type ionotropic glutamate receptor (iGluR) subunit proteins, using an in situ blotting technique (histoblot) (Kopniczky et al., 2005). In brief, animals were deeply anesthetized and decapitated, and the brains were quickly frozen in isopentane and stored at $-80^{\circ} \mathrm{C}$ until sectioning. Horizontal cryostat sections $(10 \mu \mathrm{m})$ were apposed to nitrocellulose membranes, which were previously moistened with $48 \mathrm{~mm}$ Tris base, $39 \mathrm{~mm}$ glycine, $2 \%$ (w/v) SDS, and 20\% $(\mathrm{v} / \mathrm{v})$ methanol for $15 \mathrm{~min}$ at room temperature. After blocking in 5\% $(\mathrm{w} / \mathrm{v})$ nonfat dry milk in PBS, nitrocellulose membranes were DNase I treated $(5 \mathrm{U} / \mathrm{ml})$, washed, and incubated in $2 \%(\mathrm{w} / \mathrm{v})$ SDS and, $100 \mathrm{~mm}$ $\beta$-mercaptoethanol in $100 \mathrm{~mm}$ Tris- $\mathrm{HCl}, \mathrm{pH} 7.0$, for $60 \mathrm{~min}$ at $45^{\circ} \mathrm{C}$ to remove adhering tissue residues. After excessive washing, blots were reacted with affinity-purified anti-GluR1-GluR4 (Pickard et al., 2000) and 
anti-NR1 NMDA receptor (Molnar et al., 1995) subunit-specific antibodies $(0.5 \mu \mathrm{g} / \mathrm{ml})$ in blocking solution overnight at $4^{\circ} \mathrm{C}$. The bound primary antibodies were detected with alkaline phosphatase-conjugated anti-rabbit IgG secondary antibody (Tonnes et al., 1999). To facilitate the identification of structures and cell layers, adjacent cryostat sections were stained with cresyl violet. Digital images were acquired by scanning the membranes using a desktop scanner. Image analysis and processing were performed using the Adobe Photoshop software (Adobe Systems, San Jose, CA). When processing the images, each was treated identically to allow comparison of pixel densities in different hippocampal and cortical regions. The pixel density of immunoreactivity was measured by an experimenter blind to the experimental conditions using a previously established quantification strategy (Kopniczky et al., 2005). Briefly, open circular cursors with a diameter of $0.30 \mathrm{~mm}$ were placed on the striatum (eight circles) and perirhinal cortex (four circles; as illustrated in Fig. 7A), and smaller circles (diameter, $0.10 \mathrm{~mm}$ ) were placed at adjacent positions along the stratum oriens (eight circles), stratum radiatum (six circles), stratum lacunosum moleculare (seven circles), stratum moleculare of dentate gyrus (12 circles), hilum of dentate gyrus (six circles), and stratum lucidum of CA3 (seven circles; as illustrated in Fig. $7 B$ ). The average of 10 background determinations (performed near the brain proteincontaining areas of the immunostained nitrocellulose papers) was subtracted from the average pixel densities measured within various hippocampal regions. After background corrections, the average pixel density for the whole subregion of the hippocampus or cortex from one animal counted as one $n$. Differences between the corresponding hippocampal regions of $m G l u R 7^{+/+}$and $m G l u R 7^{-/-}$animals were assessed using a two-way ANOVA and further compared with the Bonferroni's post hoc test, at a minimum confidence level of $p<0.05$.

\section{Statistical analysis}

Data are presented as mean \pm SEM. Differences between mean values were determined using two-tailed $t$ tests or ANOVA procedures with Bonferroni's corrections for post hoc comparisons. Differences of $p<$ 0.05 were considered significant.

\section{Results}

Neuromotor and visual performance

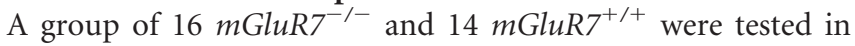
neuromotor tests, exploratory behavior, passive avoidance, and CER.

No gross behavioral differences between the $m G l u R 7^{+/+}$and $m G l u R 7^{-/-}$mice were observed, including normal breeding behavior. Also, no differences were observed in neuromotor and cage activity tests between $m G l u R 7^{+/+}$and $m G l u R 7^{-/-}$mice. Cage activity was almost the same in $m G l u R 7^{+/+}$(total counts per $24 \mathrm{~h}, 11,785 \pm 1361)$ as in $m G l u R 7^{-/-}$mice $(11,749 \pm 1235)$. Grip strength was also not different between $m G l u R 7^{+/+}(455 \pm$ $24 \mathrm{mN})$ and $m G l u R 7^{-1-}(426 \pm 24 \mathrm{mN})$ mice, and $m G l u R 7^{+/+}$ stayed on average $172 \pm 19$ s on the rotarod compared with $186 \pm$ $16 \mathrm{~s}$ in $m G l u R 7^{-1-}$ mice (difference not significant).

Recordings from dark-adapted visual evoked potentials showed a distinguished peak at $45.83 \mathrm{~ms}$ (peak latency) with similar amplitude for both genotypes (data not shown), indicating that $m G l u R 7^{-1-}$ visual sensitivity was not different from $m G l u R 7^{+/+}$.

\section{Exploratory activity}

In the open-field and social exploration tasks, $m G l u R 7^{-/-}$mice showed a tendency to cover longer distances (path length) and enter the center more often than $m G l u R 7^{+/+}$(Table 1). These differences in the open-field tests were not significant, but the elevated plus maze test definitely revealed that $m G l u R 7^{-/-}$animals were more actively exploring the arena than wild-type littermates, expressed by a larger total number of arm entries in the $m G l u R 7^{-/-}$group $\left(F_{(1,56)}=10.932 ; p=0.002\right)($ Fig. $1 A)$. Nota-

\begin{tabular}{lcc}
\multicolumn{2}{l}{ Table 1. Summary of exploratory behavior in $\mathbf{m G l u R 7 ^ { - / - }}$ and $\mathbf{m G l u R 7 ^ { + / + }}$ mice } \\
\hline & $\begin{array}{l}m G l u R 7^{+/+} \\
(n=14)\end{array}$ & $\begin{array}{c}m G l u R 7^{-/-} \\
(n=16)\end{array}$ \\
\hline $\begin{array}{l}\text { Open field } \\
\text { Total path length (cm) }\end{array}$ & $1896 \pm 170$ & $2116 \pm 420$ \\
Corner entries & $43 \pm 4$ & $37 \pm 5$ \\
Entries in center & $11 \pm 2$ & $13 \pm 4$ \\
\% path length in center & $11 \pm 2$ & $11 \pm 2$ \\
Social exploration & & \\
Total path length (cm) & $2818 \pm 316$ & $2982 \pm 437$ \\
Corner entries & $39 \pm 3$ & $27 \pm 4$ \\
Entries in center & $26 \pm 4$ & $29 \pm 5$ \\
\% path length in center & $23 \pm 5$ & $31 \pm 5$ \\
\hline
\end{tabular}

A
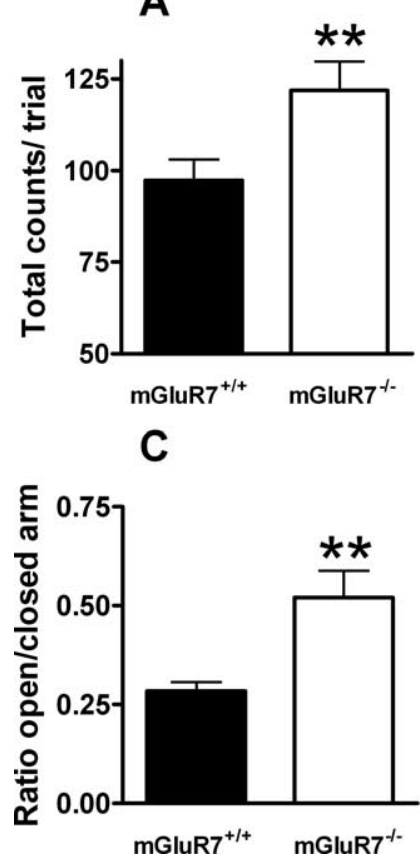

B
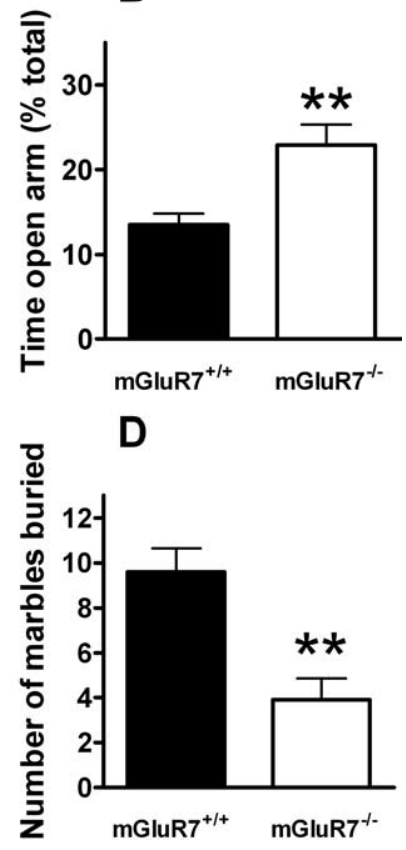

Figure 1. Elevated plus maze performance and marble-burying task in $m G l u R 7^{+/+}$(black bars) and $m G l u R 7^{-1-}$ (white bars) mice. Total number of arm entries were recorded during a $10 \mathrm{~min} \operatorname{trial}(\boldsymbol{A})$ as well as time spent in the open arms $(\boldsymbol{B})$ and number of crossings into the open versus closed arms (C). $m G l u R 7^{-1-}$ mice were generally more active during this test but also showed anxiolytic-like behavior because they spent more time and entered more in the open arms than $m G / u R 7^{+/+}$. The marble-burying task revealed significantly fewer marbles buried by $m G l u R 7^{-/-}$. Values are expressed as mean $\pm S E M ;{ }^{* *} p<0.01$, significant difference between $m G l u R 7^{+/+}$and $m G l u R 7^{-/-}$values.

bly, $m G l u R 7^{-1-}$ animals spent more time in the open arms than wild types $\left(F_{(1,56)}=6.308 ; p=0.015\right)($ Fig. $1 B)$ and also showed relatively more open-arm activity compared with $m G l u R 7^{+/+}$ littermates $\left(F_{(1,56)}=10.202 ; p=0.002\right)$ (Fig. 1C). These latter measures indicate that the increase in open-arm exploration in the $m G l u R 7^{-1-}$ group cannot be reduced to increased locomotor activity. The assessment of behavior in the elevated plus maze was done in two different experimental groups at two different time points. The data were not different and were pooled, resulting in a group of $n=28$ and 30 for $m G l u R 7^{+/+}$and $m G l u R 7^{-/-}$, respectively.

A naive, gender-mixed group of mice ( $n=28$ and 30 for $m G l u R 7^{+/+}$and $m G l u R 7^{-1-}$, respectively) were tested in the marble-burying task. $m G l u R 7^{-/-}$buried significantly fewer marbles during the $30 \mathrm{~min}$ trial than their wild-type littermates $\left(F_{(1,56)}=16.33 ; p<0.001\right)($ Fig. $1 D)$. 
Learning and memory tasks

In the passive avoidance task, $m G l u R 7^{-/-}$had a reduced latency to enter the unknown dark compartment compared with $m G l u R 7^{+/+}[33 \mathrm{~s}(11.75 / 105)$ and $20 \mathrm{~s}(13 / 44)$ expressed as median $\left(25 / 75\right.$ percentile) for $m G l u R 7^{+/+}$and $m G l u R 7^{-/-}$, respectively], but the difference was not significant (Kruskal-Wallis one-way ANOVA; $p=0.772$ ). After the experience of a footshock, both groups would not enter the dark compartment within the allotted 5 min.

A naive gender-mixed group of mice were assessed in the Morris water maze task $\left(n=26\right.$ and 31 for $m G l u R 7^{+/+}$and $m G l u R 7^{-/-}$, respectively). During the acquisition trial blocks, both groups learned the position of the hidden platform, which is revealed by a significant main effect of trial block $\left(F_{(12,456)}=\right.$ 68.914; $p<0.001$ ). However, $m G l u R 7^{-1-}$ animals displayed a significant delay in acquiring this task compared with their wildtype littermates $\left(F_{(1,38)}=11.348 ; p<0.005\right)$ (Fig. $\left.2 A\right)$, with no significant interaction ( $p=0.092)$. This effect can only partly be explained by the slightly but significantly lower swim speed of $m G l u R 7^{-1-}\left(F_{(1,37)}=7.455 ; p=0.01\right)$ (Fig. $2 B$, inset). In contrast, the time spent near the wall, a measure for thigmotaxis, decreased in a similar manner to the latency over the 13 acquisition trials, but ANOVA revealed no significant effect between $m G l u R 7^{+/+}$and $m G l u R 7^{-/-}$. At the end of a trial week, probe trials were performed in the afternoon (i.e., after trial block 5, 10, and 13) (Fig. 2C). Whereas $m G l u R 7^{+/+}$displayed a clear preference for the target quadrant already after 10 trial blocks, the $m G l u R 7^{-1-}$ needed at least three more trial blocks to show a reliable target quadrant preference, which is revealed in a significant difference between genotypes in time spent in target quadrant during probe trial $2\left(F_{(1,56)}=7.382 ; p=0.009\right)$. The statistical analysis over all three probe trials using ANOVA with probe trial and genotype as variables found significant main effects of probe trial $\left(F_{(2,164)}=9.361 ; p<0.001\right)$ and genotype $\left(F_{(1,164)}=\right.$ $11.811 ; p<0.005)$, without reliable interaction. The results from the three probe trials suggest that $m G l u R 7^{+/+}$mice were somewhat quicker to acquire information about the location of the platform than $m G l u R 7^{-1-}$ mice.

Working memory was assessed in the Morris water maze by daily changing the location of the hidden platform. In the cued trials (Fig. 3A), $m G l u R 7^{-/-}$mice were consistently slower in finding the hidden platform than their $m G l u R 7^{+/+}$littermates $\left(F_{(1,22)}=4.708 ; p<0.05\right)$, whereas in the uncued trials (Fig. $3 B$ ), both $m G l u R 7^{-1-}$ and $m G l u R 7^{+/+}$displayed the same latency to find the hidden platform. We also measured the savings between swim 1 and 2 by subtracting the individual latencies and averaging the group mean savings over the $6 \mathrm{~d}$ trial period (Fig. $3 C$ ). Overall, $m G l u R 7^{+/+}$show an increased saving from swim 1 to 2 when compared with $m G l u R 7^{-1-}$, but this difference is not significant because of the large variations $(10.52 \pm 3.6$ and $3.9 \pm 3.2$ for $m G l u R 7^{+/+}$and $m G l u R 7^{-/-}$, respectively). However, the comparison between cued and non-cued trials reveals that $m G l u R 7^{+/+}$display a significantly increased saving in cued trials $\left(F_{(1.127)}=7.312 ; p<0.01\right)$. In contrast, $m G l u R 7^{-1-}$ show no difference in saving whether a cue is presented or not $\left(F_{(1,176)}=\right.$ $0.417 ; p=0.5)$. This suggests that $m G l u R 7^{+/+}$are solving the matching-to-position task better because of a superior shortterm memory, whereas $m G l u R 7^{-/-}$show equal performance in both trial setups.

In the extinction trials, a significant difference in swimming behavior was observed. Over 3 extinction days, the time spent in the target quadrant was significantly reduced to chance level (Fig. $4 A)$. ANOVA with day and genotype as variables revealed a
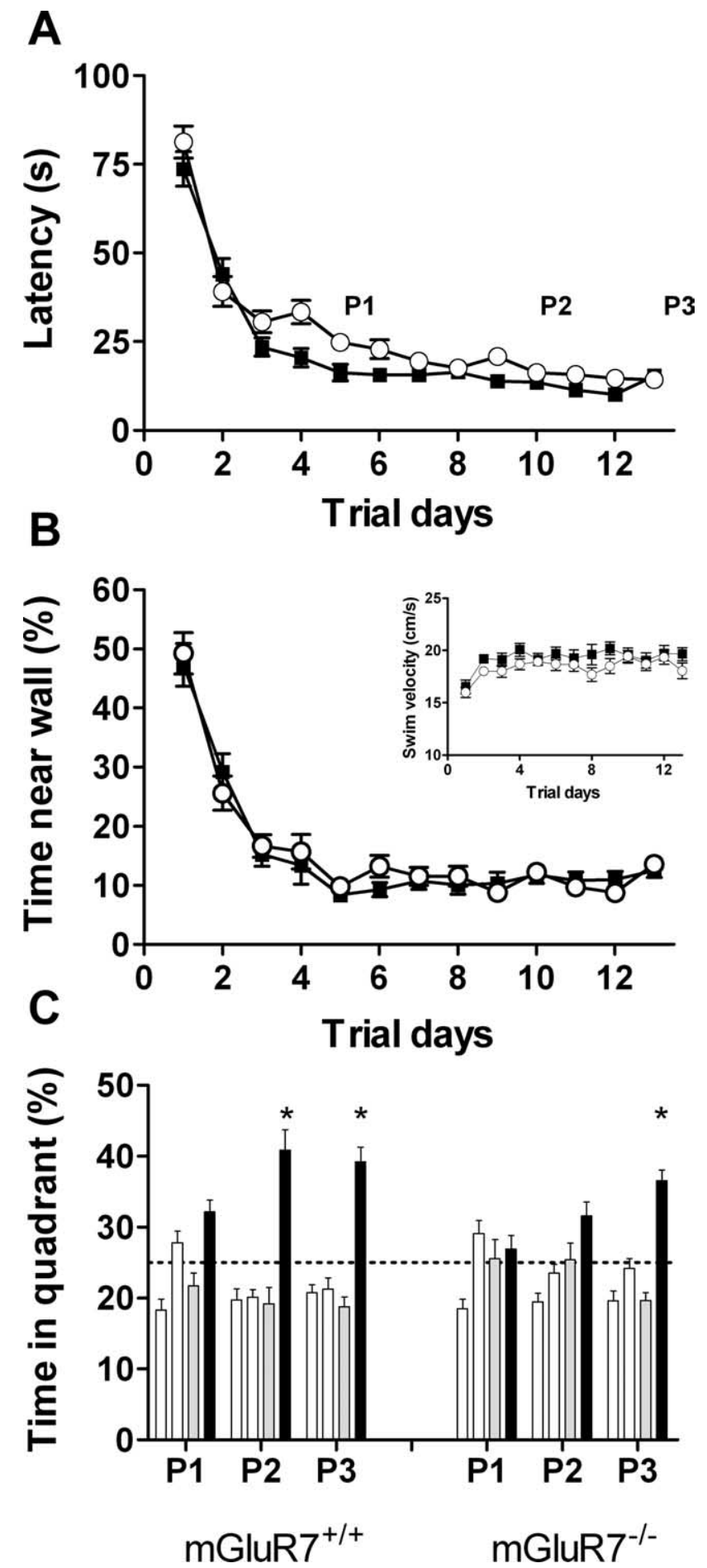

Figure 2. Fixed-platform water maze performance in $m G l u R 7^{-/-}$mice and wild-type littermates. All mice learned to find the submerged platform during 13 consecutive trial blocks $(\boldsymbol{A})$, but, when measuring the mean escape latency, it took $m G l u R 7^{-1-}$ (open circles) significantly longer than $m G l u R 7^{+/+}$(filled squares) to find the hidden platform ( $n=26-31$ per group), which is only partly attributable to the reduced swim speed in $m G l u R 7^{-/-}$(see inset). In contrast, when measuring the time the animals spent near the wall, both groups quickly abandoned the thigmotactic behavior ( $\boldsymbol{B}$; difference not significant) and searched actively for the hidden platform. Three interspersed probe trials (P1-P3) were performed to evaluate whether the animals had developed spatial preference for the target quadrant (C). Total time in each quadrant (i.e., target, black bar; opposite target, gray bar; adjacent 1 and 2, white bars) is plotted for each probe trial, expressed as mean \pm SEM. Whereas $m G l u R 7^{+/+}$show a clearly established preference for the target quadrant already at probe $2, m G l u R 7^{-1-}$ show a significant preference for target quadrant only at probe $3 .{ }^{* *} p<0.01$, significant preference for the target quadrant. 


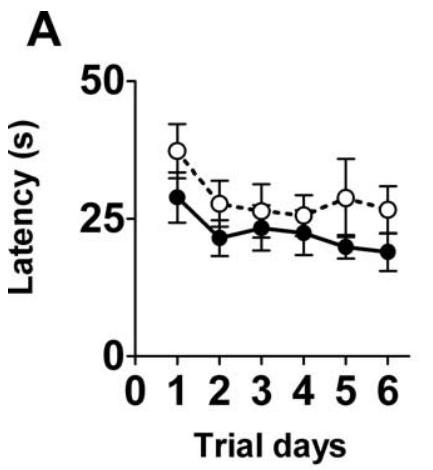

B

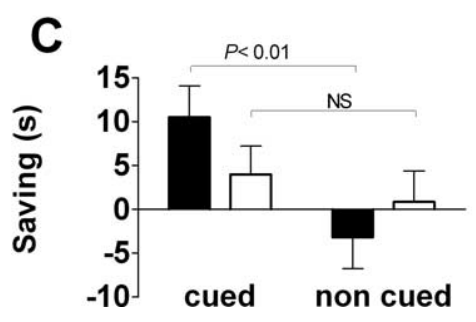

Figure 3. Assessment of working memory in the water maze task in $m G l u R 7^{+/+}$(filled circles) and $m G l u R 7^{-1-}$ (open circles) mice. In daily trial blocks of five swims, mice had to find a hidden platform with daily changing location of the platform. During the cued matching-toposition experiment (first swim indicates platform location for the following 4 swims), mGluR $7^{+/+}$mice found the hidden platform slightly faster than $m G l u R 7^{-1-}$ mice $(\boldsymbol{A} ; p<$ 0.05). During the uncued experiment (platform location during first swim opposite location of the following 4 swims), both genotypes needed a similar amount of time to find the hidden platform $(\boldsymbol{B})$. Data are means \pm SEM for swim 2-5, averaged by genotype. Savings in escape latency between swim 1 and 2 during cued matching-to-position experiment was increased in $m G l u R 7^{+/+}$mice, but the difference was not significant (C). The comparison between cued and uncued experiment revealed that $m G l u R 7^{+/+}$(black bars) display a significantly larger saving when presented with a cue than without $\left(p<0.01\right.$ ), whereas $m G / u R 7^{-1-}$ (white bars) show similar performance. Values are means \pm SEM for individual swim 1-swim 2 latencies averaged over 6 trial days.

highly significant main effect for day $\left(F_{(2,78)}=28.052 ; p<0.001\right)$ and genotype $\left(F_{(1,78)}=3.952 ; p=0.05\right)$, indicating that, over $3 \mathrm{~d}$ of extinction trials, the mice abandon their spatial preference for one quadrant and change their search pattern. This is also illustrated by the time spent near the wall (Fig. $4 B$ ), which increases in both groups over the 3 extinction days. However, $m G l u R 7^{+/+}$ were much quicker to adopt a new search strategy than their $m G l u R 7^{-1-}$ counterparts. ANOVA with day and genotype as variables revealed a significant main effect for day $\left(F_{(2,78)}=\right.$ $16.154 ; p<0.001)$ and genotype $\left(F_{(1,78)}=20.15 ; p<0.001\right)$, with no reliable interaction. In parallel, over the 3 extinction days, swim speed was significantly reduced $\left(F_{(2,78)}=4.75 ; p=0.011\right)$, but no difference between the genotypes was observed ( $p=0.08$ ) (Fig. $4 D$ ). Whereas swim speed reduced over the extinction days, the amount of time spent floating increased slightly but significantly $\left(F_{(2,78)}=4.325 ; p=0.017\right)$ (Fig. $\left.4 C\right)$.

A naive gender-mixed group of mice were assessed in the radial arm maze task $\left(n=18\right.$ and 12 for $m G l u R 7^{+/+}$and $m G l u R 7^{-1-}$, respectively). Over several weeks, subjects were trained to retrieve pellets from food wells located in an eight-arm radial maze (Fig. 5). Non-visits or repeat visits during a trial were counted as errors. $m G l u R 7^{+/+}$mice quickly learned to retrieve all eight food pellets within five training trials in the radial arm maze task and maintained a low error margin throughout the acquisition period. Conversely, $m G l u R 7^{-/-}$showed variable and inconsistent ability to learn to retrieve food pellets from the maze, and there was a significant difference in number of errors between the genotypes $\left(F_{(1,26)}=9.868 ; p=0.004\right)$.
A
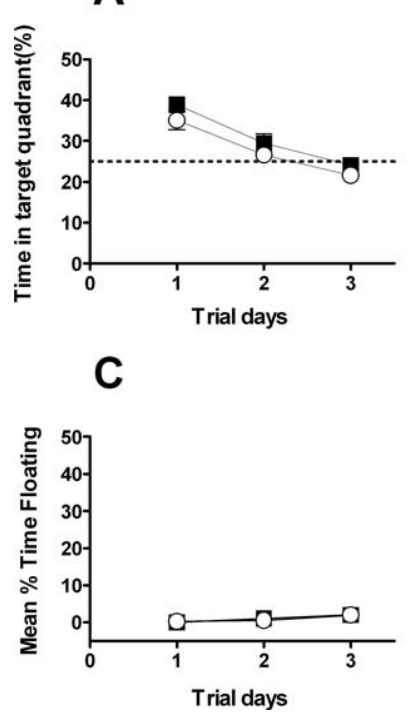

B
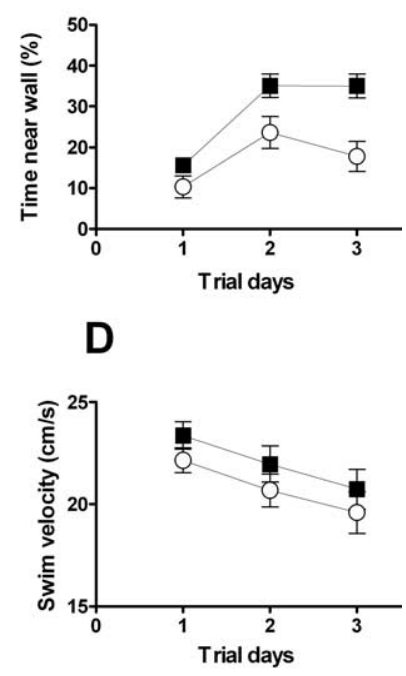

Figure 4. Extinction of spatial reference memory in Morris water maze. After both groups had learned the position of the hidden platform by swimming preferentially in the target quadrant during probe trials, 3 extinction days were performed with the platform removed. Two, three, and three trial blocks per day were conducted, each trial block consisting of four swim trials. Already on day 2, both groups quickly abandon the preference for the former target quadrant $(\boldsymbol{A})$. A detailed analysis of the swim paths revealed a very different search strategy between the two groups. Whereas $m G l u R 7^{+/+}$(filled squares) quickly stopped searching in the center and started swimming closer to the wall, $m G l u R 7^{-1-}$ (open circles) continued to search in the center for the platform and display less thigmotactic behavior $(\boldsymbol{B})$. That this is part of an active searching strategy is also indicated by the relatively small increase of floating behavior $(\boldsymbol{C})$ and reduction in swim speed $(\boldsymbol{D})$.

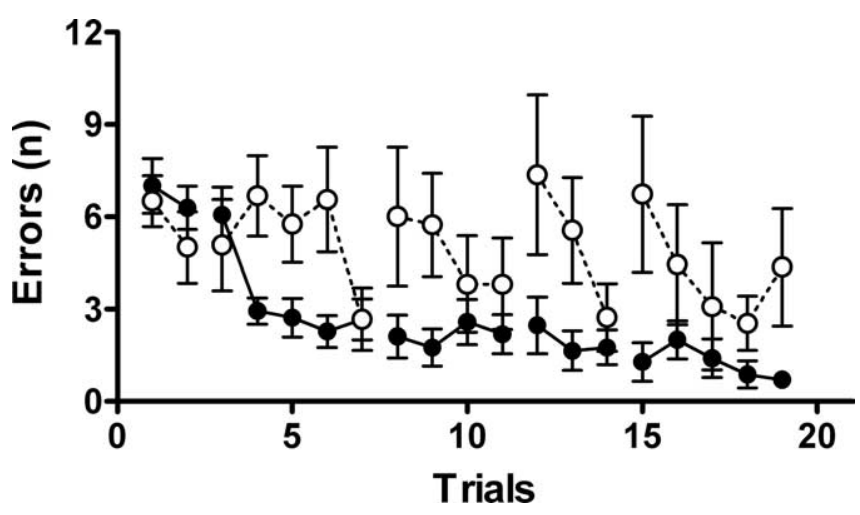

Figure 5. Radial arm maze acquisition performance in $m G l u R 7^{-1-}$ (open circles) and $m G l u R 7^{+/+}$(filled circles). Over several weeks, subjects were trained to retrieve pellets from food wells located in the eight arms of the radial maze. Non-visits or repeat visits were counted as errors, and a trial lasted 5 min or until all pellets were retrieved. $m G l u R 7^{+/+}$mice were faster in learning to retrieve all pellets compared with $m G l u R 7^{-1-}$ mice $(p=0.004)$, which were more variable and inconsistent in their performance. Values are means \pm SEM of counted errors.

However, in the delayed, non-matching-to-sample task, no difference in error performance was observed between the two genotypes (data not shown).

\section{CER acquisition and extinction}

The CER task for fear conditioning revealed significant differences between the two genotypes. During the initial training sessions (Fig. 6A), both genotypes displayed a robust increase of nose poking and reached stable performance (16-20 nose pokes/ min) during the final VI-30s trials. Throughout the initial ses- 
A

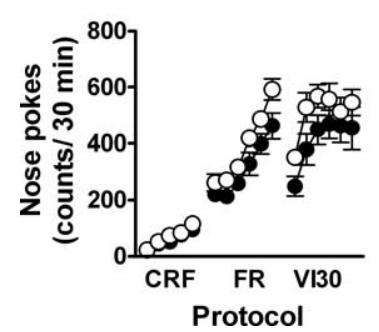

B

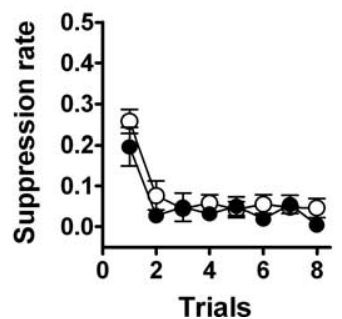

Figure 6. Food-rewarded operant conditioning and CER in $m G l u R 7^{-1-}$ (open symbols) and wild-type (filled symbols) mice. During the operant sessions $(\boldsymbol{A})$, food-deprived mice were trained to nose poke for food pellets by positive reinforcement (CRF, FR-5 and FR-10, and VI-30s trials). On establishing a stable response rate, eight (ER acquisition trials ( $\boldsymbol{B}$ ) were followed by eight CER extinction trials (C). Both genotypes displayed similar response suppression during the acquisition trials, but, during extinction, $m G l u R 7^{+/+}$mice resumed instrumental responding significantly faster than $m G l u R 7^{-/-}$(see Results). Values are means \pm SEM.

sions, $m G l u R 7^{-1-}$ mice displayed a slightly higher response rate than their $m G l u R 7^{+/+}$littermates $\left(F_{(1,26)}=4.69 ; p=0.04\right)$, but genotype did not interact with session. In the eight CER sessions (acquisition of conditioned fear), both genotypes displayed a rapid suppression of nose poking, reaching almost complete suppression by the second CER trial (Fig. $6 B$ ). During eight subsequent tone-alone trials (Fig. $6 C$ ), both groups gradually resumed nose poking $\left(F_{(7,182)}=39.15 ; p<0.001\right)$. Fear-elicited suppression during these latter trials proved more resistant to extinction in the $m G l u R 7^{-1-}$ than in $m G l u R 7^{+/+}$littermates $\left(F_{(1,26)}=5.91\right.$; $p=0.022)$. The significant interaction between session and genotype $\left(F_{(7,182)}=2.85 ; p=0.008\right)$ indicates that $m G l u R 7^{-/-}$ started from a similar level as controls but lagged approximately three sessions behind in recovery from conditioned fear and eventually attained extinction of fear-elicited suppression equivalent to $m G l u R^{+/+}$mice.

\section{Characterization of AMPA and NMDA receptor protein expression in control and $m G l u R 7^{-1-}$ mice brain samples} To identify possible differences in the expression pattern of AMPA and NMDA receptors, adjacent horizontal sections of whole unfixed $m G l u R 7^{+/+}$and $m G l u R 7^{-1-}$ brains were blotted onto nitrocellulose membranes before immunostaining as described previously (Tonnes et al., 1999). This histoblot method is a reliable and convenient way to compare the regional distribution and expression pattern of different receptor proteins in the brain (Kopniczky et al., 2005). An antibody raised against the conserved transmembrane 3-4 linker region was used to recognize all AMPA receptor subunits (GluR1-GluR4 flip and flop) (Pickard et al., 2000). To study the expression pattern of NMDA receptor proteins, the NR1 subunit was investigated, which is an essential component of all known NMDA receptor heterooligomers. The AMPA receptor subunits GluR1-GluR4 were localized in strata oriens, radiatum, and lacunosum-moleculare of CA1-CA3, in the molecular layer of the dentate gyrus, and in the superficial layers of neocortex (Fig. 7C). The NR1 NMDA receptor subunit immunoreactivity was prominent in the strata oriens and radiatum of $\mathrm{CA} 1$, in the outer molecular layer of the dentate gyrus, and in the superficial layers of neocortex (Fig. 7D).

Densitometry analysis was performed to compare the immunoreactivity in the corresponding hippocampal and cortical regions of $m G l u R 7^{+/+}$and $m G l u R 7^{-/-}$brains. There were no detectable changes in the density of GluR1-GluR4 AMPA receptor and NR1 NMDA receptor subunit staining in any of the brain regions investigated (Fig. $7 C, D$ ).

C

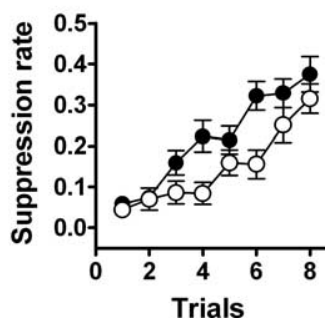

\section{Discussion}

Fear and anxiety disorders are a major public health concern (National Institute of Mental Health, 2001). These disorders are often resistant to current therapeutic approaches such as anxiolytic drug treatment and cognitive behavior therapy. Novel treatment strategies are required, and manipulations of the glutamatergic system through mGluRs are widely considered the most promising avenue (Swanson et al., 2005). In the present study, we uncovered specific differences between $m G l u R 7^{-1-}$ mice and their wild-type littermates in anxiety-related tests and fear conditioning. We found a significant impairment in reference memory acquisition and spatial working memory. Furthermore, we found a resistance to extinction in a Morris water maze task as well as in an emotional response model in $m G l u R 7^{-1-}$ mice. These latter findings are of particular importance in view of a putative neurocognitive association between working memory and extinction, the involvement of mGluR7 in fear and anxietyrelated behaviors, and their possible implications for the psychopharmacological and behavioral treatment of fear and anxiety disorders (LeDoux, 1998).

Previous studies of $m G l u R 7^{-1-}$ mouse brains established the lack of gross histological abnormalities or compensatory changes in mGluR4 or mGluR8 expression (Sansig et al., 2001). Our present results show that changes in AMPA and NMDA receptor expression, which could also have contributed to the $m G l u R 7^{-1-}$ behavioral phenotype (Falls et al., 1992), did not occur in $m G l u R 7^{-/-}$mice either.

\section{Working memory defects}

The moving platform water maze and radial arm maze protocols are used to assess working memory in laboratory rodents (Hodges, 1996). In rodent tasks, working memory defines a cognitive process to store and manipulate information relevant only for a short period of time or within a session (Dudchenko, 2004). Our present observations support a critical role of mGluR7 in spatial working memory functioning. The results of the initial water maze training indicate a deficit in task acquisition, but, after continued training, $m G l u R 7^{-1-}$ mice eventually reached similar proficiency levels as wild-type controls. Most significantly, the results of the moving-platform trials specifically show a spatial working memory deficit. During the cued, matching-toposition trials, $m G l u R 7^{+/+}$benefited from being cued to the location of the platform in the first trial, whereas $m G l u R 7^{-/-}$were less able to use such working memory information, which was confirmed by more savings between swim 1 and 2 in $m G l u R 7^{+/+}$. During the uncued trials, in which the first trial did not refer the animals to the actual position of the escape platform, performance turned out to be similar in both genotype groups, and savings in both groups were reduced or negative.

It was demonstrated previously that matching-to-position working memory performance in water maze was especially sensitive to hippocampal impairment (Astur et al., 2002; Ferbinteanu et al., 2003; de Hoz et al., 2005). A specific role of the glutamatergic system therein is supported by findings of memory impairment caused by blocking of hippocampal NMDA receptors (Steele and Morris, 1999). Holscher et al. (2004) observed deficits in spatial working memory in $m G l u R 7^{-1-}$ mice, whereas 
their long-term memory performance was unaltered in a radial arm maze. Our data expand this to working memory deficits in spatial cue experiments using the water maze and further support the crucial involvement of mGluR7 and other glutamate receptors in various memory processes (Riedel et al., 2003).

\section{Delayed extinction of} conditioned responses

A second important new finding was the delayed extinction in $m G l u R 7^{-1-}$ mice of learned spatial preference in the Morris water maze and of conditioned fear responses in the CER procedure. In contrast, expression or acquisition of conditioned fear appeared to be unaltered. The only other evidence for a role of group III mGluR in fear and anxiety-related behavior comes from studies in $m G l u R 7^{-/-}$ mice displaying reduced shock-induced freezing and impaired conditioned taste aversion (Masugi et al., 1999) and reduced anxiety in the elevated plus maze and several depression-like behaviors (Cryan et al., 2003). In contrast to group III mGluR, the involvement of group I or group II receptors in fear and anxiety-related behavior is relatively well established (Swanson et al., 2005). Injection of group I (mGluR1 and mGluR5) antagonists elicited dosedependent anxiolytic behavior in elevated plus maze, social exploration, and defensive burying, as well as inhibited fearpotentiated startle and contextual fear conditioning (Spooren et al., 2000; Tatarczynska et al., 2001; Pietraszek et al., 2005). In contrast, administration of a group II agonist evoked anxiolytic activity in the elevated plus maze (Monn et al., 1997; Helton et al., 1998), whereas elevated plus maze performance and social interaction were unaltered by injecting a group II antagonist (Chaki et al., 2004). In summary, it now appears that all three mGluR groups are important mediators of fear and anxiety.

Impairments in fear conditioning have been reported to coincide with anxiolytic behaviors in rodents (Weiss et al., 2000). In $m G l u R 7^{-1-}$ mice, we presently show anxiolytic-like behavior in the elevated plus maze and marble-burying task that is dissociated from their delayed fear extinction. Although these observations seem paradoxical, serotonin-3A receptor knock-out mice, part of a group of well established anxiety models, also displayed decreased anxiety in the elevated plus maze, unaltered open-field exploration, and enhanced fear-induced freezing (Bhatnagar et al., 2004). This is also in accordance with fear extinction being inhibited by anxiolytic benzodiazepine receptor ligands (Harris and Westbrook, 1998).

A

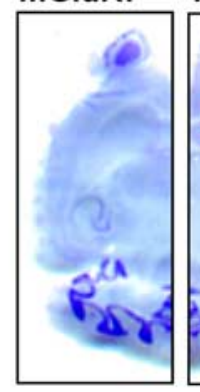

C

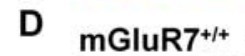

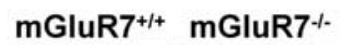

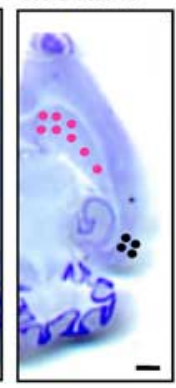

B
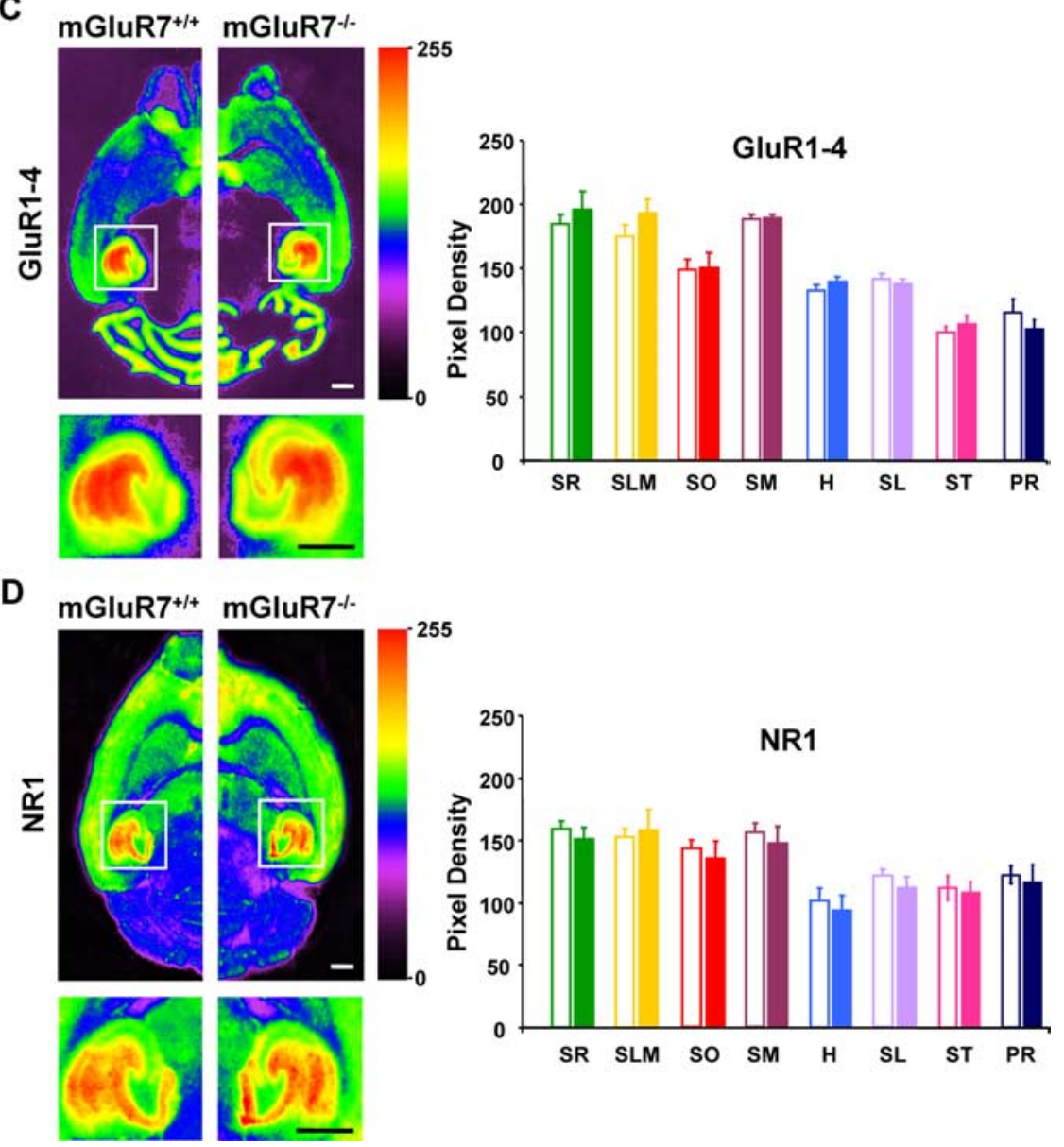

Figure 7. Comparison of AMPA and NMDA receptor subunit protein expression in control and $m G / u R 7^{-/-}$brains. $\boldsymbol{A}$, Nisslstained adjacent sections were used to identify the different brain regions after immunostaining. Cyclamen and dark blue dots indicate the sampling sites for striatum ( 8 circles with a diameter of $0.3 \mathrm{~mm}$ ) and the perirhinal cortex ( 4 circles with a diameter of $0.3 \mathrm{~mm}$ ), respectively. $\boldsymbol{B}$, Schematic diagram illustrating the sampling method used to compare immunoreactivities in different hippocampal regions (for details, see Materials and Methods). The colors represent layers of the hippocampal formation: red, stratum oriens (SO); green, stratum radiatum (SR); yellow, stratum lacunosum-moleculare (SLM); plum, stratum moleculare of dentate gyrus (SM); blue, hilum of dentate gyrus (H); lilac, stratum lucidum of CA3 (SL); pink, striatum (ST); dark blue, perirhinal cortex (PR). Density readings were taken by placing open circular cursors with a diameter of $0.1 \mathrm{~mm}$ at the indicated adjacent positions along SO (8), SR (6), SLM (7), SM (12), H (6), and SL (7). C, D, Representative histoblots of corresponding regions of $m G l u R 7^{+/+}$and $m G l u R 7^{-/-}$brains immunostained with antibodies against GluR1-GluR4 (C) or NR1 (D) iGluR subunit proteins. For illustration proposes, grayscale histoblot images were converted to color gradients using gradient mapping. Scale bars, $1 \mathrm{~mm}$. The bar diagrams indicate the pixel density levels (arbitrary units) in various hippocampal and cortical regions in $m G / u R 7^{+/+}$ (open bars) and $m G l u R 7^{-/-}$(filled bars) animals for the indicated iGluR subunit proteins. Quantitative comparison revealed no significant differences $(p>0.05)$.

\section{Concurrence of working memory and extinction}

The cognitive basis of extinction is a matter of debate, but it has been demonstrated that the disappearance of the conditioned response does not reflect a parallel disappearance of the underly- 
ing conditioned stimulus- unconditioned stimulus association at the cognitive, representational level. Instead, extinction treatment generates new (inhibitory) context-dependent learning (Bouton, 2002, 2004). In human subjects, concurrent working memory performance interferes with Pavlovian fear conditioning, indicating that fear response acquisition in humans is a learning phenomenon that may also depend on higher-level cognitive processes (Carter et al., 2003). Concurrence of deficits in working memory and conditioned fear extinction in $m G l u R 7^{-1-}$ mice suggests that suppression of conditioned fear during extinction training may rely on working memory resources, similar to other forms of fear suppression in rats (Beckers et al., 2006).

Our suggestion of a role of mGluR in extinction is consistent with current knowledge about the relevant signaling pathways and neuroanatomical regions. Extinction requires an intact glutamate receptor signaling pathway and induces gene expression and protein synthesis in the basolateral amygdala, hippocampus, and insular cortex (Berman and Dudai, 2001; Lu et al., 2001; Myers and Davis, 2002; Walker et al., 2002; Quirk and Gehlert, 2003; Szapiro et al., 2003; Vianna et al., 2003). Intra-amygdala infusion of an NMDA antagonist blocks conditioned fear extinction (Falls et al., 1992), and amygdalar NMDA receptors are involved in the acquisition but not in the expression of fear responses (Miserendino et al., 1990). This suggests that acquisition and extinction share a common mechanism, but Cain et al. (2002) argued that the neuroplasticity underlying extinction involves L-type voltage-gated calcium channels rather than NMDA receptors. This and other evidence indicates that some processes underlying extinction might be distinct from those involved in acquisition or expression of fear responses (Cain et al., 2002; Barrett et al., 2003; Anglada-Figueroa and Quirk, 2005).

Specific CNS regions are involved during extinction, including prefrontal cortex, medial thalamus, and hippocampus (Maren, 2001; Barrett et al., 2003). Metabolic mapping during extinction revealed extensive interaction between several thalamic nuclei and hippocampal formation, which was negatively correlated to prefrontal cortex activation (Barrett et al., 2003). There is considerable overlap between the neuroanatomical distribution of mGluR7 and brain regions involved in fear response conditioning, most strikingly those involved in extinction. Kinoshita et al. (1998) showed a distinct distribution pattern of mGluR7 with abundant expression in several telencephalic regions, most prominently the amygdalo-hippocampal area and the entire neocortex, with low expression levels in diencephalon, brainstem, and cerebellar cortex. The deficit observed in $m G l u R 7^{-1-}$ mice during the CER experiment affects behavioral inhibition of conditioned fear but obviously not, or to a lesser degree, initial acquisition of the fear response. This may relate to the different brain structures putatively underlying acquisition (amygdala) and extinction (hippocampus and prefrontal cortex). Notably, hippocampus and prefrontal cortex are also involved in working memory processes that contribute to memory consolidation (Ranganath et al., 2005).

\section{Conclusion}

The present findings indicate that mGluR7 could be involved in the neurobiological mechanism(s) underlying the conceptually diverse phenomena of anxiety, fear extinction, and spatial working memory, but, at present, there is little literature support for such a common mechanism. Nevertheless, recent studies revealed that theta activity in hippocampus was increased in $m G l u R 7^{-/-}$mice and that this alteration of rhythmic activity was associated with the working memory defect (Holscher et al.,
2005). It has been demonstrated that increases in the amygdalohippocampal area also coincide with fear conditioning and expression of anxiety and fear-related responses (Seidenbecher et al., 2003). We presently show that anxiety, extinction of conditioned responses, and working memory are indeed impaired in $m G l u R 7^{-1-}$ mice, and mGluR7 involvement in these neurobehavioral phenomena is thus suggested.

\section{References}

Anglada-Figueroa D, Quirk GJ (2005) Lesions of the basal amygdala block expression of conditioned fear but not extinction. J Neurosci 25:9680-9685.

Astur RS, Taylor LB, Mamelak AN, Philpott L, Sutherland RJ (2002) Humans with hippocampus damage display severe spatial memory impairments in a virtual Morris water task. Behav Brain Res 132:77-84.

Barrett D, Shumake J, Jones D, Gonzalez-Lima F (2003) Metabolic mapping of mouse brain activity after extinction of a conditioned emotional response. J Neurosci 23:5740-5749.

Beckers T, Miller RR, De Houwer J, Urushihara K (2006) Reasoning rats: forward blocking in Pavlovian animal conditioning is sensitive to constraints of causal inference. J Exp Psychol Gen 135:92-102.

Berman DE, Dudai Y (2001) Memory extinction, learning anew, and learning the new: dissociations in the molecular machinery of learning in cortex. Science 291:2417-2419.

Bhatnagar S, Sun LM, Raber J, Maren S, Julius D, Dallman MF (2004) Changes in anxiety-related behaviors and hypothalamic-pituitaryadrenal activity in mice lacking the 5-HT-3A receptor. Physiol Behav 81:545-555.

Borsini F, Podhorna J, Marazziti D (2002) Do animal models of anxiety predict anxiolytic-like effects of antidepressants? Psychopharmacology (Berl) 163:121-141.

Bouton ME (2002) Context, ambiguity, and unlearning: sources of relapse after behavioral extinction. Biol Psychiatry 52:976-986.

Bouton ME (2004) Context and behavioral processes in extinction. Learn Mem 11:485-494.

Cain CK, Blouin AM, Barad M (2002) L-type voltage-gated calcium channels are required for extinction, but not for acquisition or expression, of conditional fear in mice. J Neurosci 22:9113-9121.

Carter RM, Hofstotter C, Tsuchiya N, Koch C (2003) Working memory and fear conditioning. Proc Natl Acad Sci USA 100:1399-1404.

Chaki S, Yoshikawa R, Hirota S, Shimazaki T, Maeda M, Kawashima N, Yoshimizu T, Yasuhara A, Sakagami K, Okuyama S, Nakanishi S, Nakazato A (2004) MGS0039: a potent and selective group II metabotropic glutamate receptor antagonist with antidepressant-like activity. Neuropharmacology 46:457-467.

Craske MG, Hermans D, Vansteenwegen D (2006) Fear and learning: from basic processes to clinical implications. Washington, DC: American Psychological Association.

Cryan JF, Holmes A (2005) The ascent of mouse: advances in modelling human depression and anxiety. Nat Rev Drug Discov 4:775-790.

Cryan JF, Kelly PH, Neijt HC, Sansig G, Flor PJ, van Der Putten H (2003) Antidepressant and anxiolytic-like effects in mice lacking the group III metabotropic glutamate receptor mGluR7. Eur J Neurosci 17:2409-2417.

Davis M (1990) Animal models of anxiety based on classical conditioning: the conditioned emotional response (CER) and the fear-potentiated startle effect. Pharmacol Ther 47:147-165.

de Hoz L, Moser EI, Morris RG (2005) Spatial learning with unilateral and bilateral hippocampal networks. Eur J Neurosci 22:745-754.

D’Hooge R, Lullmann-Rauch R, Beckers T, Balschun D, Schwake M, Reiss K, von Figura K, Saftig P (2005) Neurocognitive and psychotiform behavioral alterations and enhanced hippocampal long-term potentiation in transgenic mice displaying neuropathological features of human $\alpha$-mannosidosis. J Neurosci 25:6539-6549.

Dudchenko PA (2004) An overview of the tasks used to test working memory in rodents. Neurosci Biobehav Rev 28:699-709.

Falls WA, Miserendino MJ, Davis M (1992) Extinction of fear-potentiated startle: blockade by infusion of an NMDA antagonist into the amygdala. J Neurosci 12:854-863.

Ferbinteanu J, Ray C, McDonald RJ (2003) Both dorsal and ventral hippocampus contribute to spatial learning in Long-Evans rats. Neurosci Lett 345:131-135. 
File SE, Seth P (2003) A review of 25 years of the social interaction test. Eur J Pharmacol 463:35-53.

Harris JA, Westbrook RF (1998) Evidence that GABA transmission mediates context-specific extinction of learned fear. Psychopharmacology (Berl) 140:105-115

Helton DR, Tizzano JP, Monn JA, Schoepp DD, Kallman MJ (1998) Anxiolytic and side-effect profile of LY354740: a potent, highly selective, orally active agonist for group II metabotropic glutamate receptors. J Pharmacol Exp Ther 284:651-660.

Hodges H (1996) Maze procedures: the radial-arm and water maze compared. Brain Res Cogn Brain Res 3:167-181.

Holscher C, Schmid S, Pilz PK, Sansig G, van der Putten H, Plappert CF (2004) Lack of the metabotropic glutamate receptor subtype 7 selectively impairs short-term working memory but not long-term memory. Behav Brain Res 154:473-481.

Holscher C, Schmid S, Pilz PK, Sansig G, van der Putten H, Plappert CF (2005) Lack of the metabotropic glutamate receptor subtype 7 selectively modulates theta rhythm and working memory. Learn Mem 12:450-455.

Kew JN, Kemp JA (2005) Ionotropic and metabotropic glutamate receptor structure and pharmacology. Psychopharmacology (Berl) 179:4-29.

Kinoshita A, Shigemoto R, Ohishi H, van der Putten H, Mizuno N (1998) Immunohistochemical localization of metabotropic glutamate receptors, mGluR7a and mGluR7b, in the central nervous system of the adult rat and mouse: a light and electron microscopic study. J Comp Neurol 393:332-352.

Kopniczky Z, Dobo E, Borbely S, Vilagi I, Detari L, Krisztin-Peva B, Bagosi A, Molnar E, Mihaly A (2005) Lateral entorhinal cortex lesions rearrange afferents, glutamate receptors, increase seizure latency and suppress seizure-induced c-fos expression in the hippocampus of adult rat. J Neurochem 95:111-124.

Lattal KM, Mullen MT, Abel T (2003) Extinction, renewal, and spontaneous recovery of a spatial preference in the water maze. Behav Neurosci 117:1017-1028.

LeDoux J (1998) Fear and the brain: where have we been, and where are we going? Biol Psychiatry 44:1229-1238.

Linden AM, Johnson BG, Peters SC, Shannon HE, Tian M, Wang Y, Yu JL, Koster A, Baez M, Schoepp DD (2002) Increased anxiety-related behavior in mice deficient for metabotropic glutamate 8 (mGlu8) receptor. Neuropharmacology 43:251-259.

Lu KT, Walker DL, Davis M (2001) Mitogen-activated protein kinase cascade in the basolateral nucleus of amygdala is involved in extinction of fear-potentiated startle. J Neurosci 21:RC162 (1-5).

Makoff A, Pilling C, Harrington K, Emson P (1996) Human metabotropic glutamate receptor type 7: molecular cloning and mRNA distribution in the CNS. Brain Res Mol Brain Res 40:165-170.

Maren S (2001) Neurobiology of Pavlovian fear conditioning. Annu Rev Neurosci 24:897-931.

Masugi M, Yokoi M, Shigemoto R, Muguruma K, Watanabe Y, Sansig G, van der Putten H, Nakanishi S (1999) Metabotropic glutamate receptor subtype 7 ablation causes deficit in fear response and conditioned taste aversion. J Neurosci 19:955-963.

Millan MJ, Lejeune F, Gobert A, Brocco M, Auclair A, Bosc C, Rivet JM, Lacoste JM, Cordi A, Dekeyne A (2000) S18616, a highly potent spiroimidazoline agonist at alpha(2)-adrenoceptors. II. Influence on monoaminergic transmission, motor function, and anxiety in comparison with dexmedetomidine and clonidine. J Pharmacol Exp Ther 295:1206-1222.

Miserendino MJ, Sananes CB, Melia KR, Davis M (1990) Blocking of acquisition but not expression of conditioned fear-potentiated startle by NMDA antagonists in the amygdala. Nature 345:716-718.

Mitsukawa K, Mombereau C, Lotscher E, Uzunov DP, van der Putten H, Flor PJ, Cryan JF (2006) Metabotropic glutamate receptor subtype 7 ablation causes dysregulation of the HPA axis and increases hippocampal BDNF protein levels: implications for stress-related psychiatric disorders. Neuropsychopharmacology 31:1112-1122.

Molnar E, Varadi A, McIlhinney RA, Ashcroft SJ (1995) Identification of functional ionotropic glutamate receptor proteins in pancreatic beta-cells and in islets of Langerhans. FEBS Lett 371:253-257.

Monn JA, Valli MJ, Massey SM, Wright RA, Salhoff CR, Johnson BG, Howe T, Alt CA, Rhodes GA, Robey RL, Griffey KR, Tizzano JP, Kallman MJ, Helton DR, Schoepp DD (1997) Design, synthesis, and pharmacological characterization of $(+)$-2-aminobicyclo[3.1.0] hexane-2,6-dicarboxylic acid (LY354740): a potent, selective, and orally active group 2 metabotropic glutamate receptor agonist possessing anticonvulsant and anxiolytic properties. J Med Chem 40:528-537.
Myers KM, Davis M (2002) Behavioral and neural analysis of extinction. Neuron 36:567-584.

National Institute of Mental Health (2001) The numbers count: mental disorders in America. In: National Institutes of Health, US Department of Health and Human Services. Bethesda, MD: National Institutes of Health.

Njung'e K, Handley SL (1991) Evaluation of marble-burying behavior as a model of anxiety. Pharmacol Biochem Behav 38:63-67.

Pavlov IP (1927) Conditioned reflexes: an investigation of the physiological activity of the cerebral cortex. London: Oxford UP.

Pickard L, Noel J, Henley JM, Collingridge GL, Molnar E (2000) Developmental changes in synaptic AMPA and NMDA receptor distribution and AMPA receptor subunit composition in living hippocampal neurons. J Neurosci 20:7922-7931.

Pietraszek M, Sukhanov I, Maciejak P, Szyndler J, Gravius A, Wislowska A, Plaznik A, Bespalov AY, Danysz W (2005) Anxiolytic-like effects of mGlu1 and mGlu5 receptor antagonists in rats. Eur J Pharmacol 514:25-34.

Quirk GJ, Gehlert DR (2003) Inhibition of the amygdala: key to pathological states? Ann NY Acad Sci 985:263-272.

Ranganath C, Cohen MX, Brozinsky CJ (2005) Working memory maintenance contributes to long-term memory formation: neural and behavioral evidence. J Cogn Neurosci 17:994-1010.

Rescorla RA (2004) Spontaneous recovery. Learn Mem 11:501-509.

Riedel G, Platt B, Micheau J (2003) Glutamate receptor function in learning and memory. Behav Brain Res 140:1-47.

Sansig G, Bushell TJ, Clarke VRJ, Rozov A, Burnashev N, Portet C, Gasparini F, Schmutz M, Klebs K, Shigemoto R, Flor PJ, Kuhn R, Knoepfel T, Schroeder M, Hampson DR, Collett VJ, Zhang C, Duvoisin RM, Collingridge GL, van der Putten H (2001) Increased seizure susceptibility in mice lacking metabotropic glutamate receptor 7. J Neurosci 21:8734-8745.

Schoepp DD (2001) Unveiling the functions of presynaptic metabotropic glutamate receptors in the central nervous system. J Pharmacol Exp Ther 299:12-20.

Seidenbecher T, Laxmi TR, Stork O, Pape HC (2003) Amygdalar and hippocampal theta rhythm synchronization during fear memory retrieval. Science 301:846-850.

Spooren WP, Vassout A, Neijt HC, Kuhn R, Gasparini F, Roux S, Porsolt RD, Gentsch C (2000) Anxiolytic-like effects of the prototypical metabotropic glutamate receptor 5 antagonist 2-methyl-6-(phenylethynyl)pyridine in rodents. J Pharmacol Exp Ther 295:1267-1275.

Steele RJ, Morris RG (1999) Delay-dependent impairment of a matchingto-place task with chronic and intrahippocampal infusion of the NMDAantagonist D-AP5. Hippocampus 9:118-136.

Stewart CA, Morris RGM (1993) The watermaze. In: Behavioural neuroscience, a practical approach (Sahgal A, ed), pp 107-122. Oxford: Oxford UP.

Swanson CJ, Bures M, Johnson MP, Linden AM, Monn JA, Schoepp DD (2005) Metabotropic glutamate receptors as novel targets for anxiety and stress disorders. Nat Rev Drug Discov 4:131-144.

Szapiro G, Vianna MR, McGaugh JL, Medina JH, Izquierdo I (2003) The role of NMDA glutamate receptors, PKA, MAPK, and CAMKII in the hippocampus in extinction of conditioned fear. Hippocampus 13:53-58.

Tatarczynska E, Klodzinska A, Chojnacka-Wojcik E, Palucha A, Gasparini F, Kuhn R, Pilc A (2001) Potential anxiolytic- and antidepressant-like effects of MPEP, a potent, selective and systemically active mGlu5 receptor antagonist. Br J Pharmacol 132:1423-1430.

Tonnes J, Stierli B, Cerletti C, Behrmann JT, Molnar E, Streit P (1999) Regional distribution and developmental changes of GluR1-flop protein revealed by monoclonal antibody in rat brain. J Neurochem 73:2195-2205.

Van Dam D, D’Hooge R, Hauben E, Reyniers E, Gantois I, Bakker CE, Oostra BA, Kooy RF, De Deyn PP (2000) Spatial learning, contextual fear conditioning and conditioned emotional response in Fmr1 knockout mice. Behav Brain Res 117:127-136.

Vianna MR, Igaz LM, Coitinho AS, Medina JH, Izquierdo I (2003) Memory extinction requires gene expression in rat hippocampus. Neurobiol Learn Mem 79:199-203.

Walker DL, Ressler KJ, Lu KT, Davis M (2002) Facilitation of conditioned fear extinction by systemic administration or intra-amygdala infusions of D-cycloserine as assessed with fear-potentiated startle in rats. J Neurosci 22:2343-2351.

Weiss SM, Lightowler S, Stanhope KJ, Kennett GA, Dourish CT (2000) Measurement of anxiety in transgenic mice. Rev Neurosci 11:59-74. 